\title{
Sağlık Hizmetleri Meslek Yüksekokullarında Verilen Eğitimle İlgili Sorunlar, Çözüm Önerileri, Uludağ Üniversitesi Sağlık Hizmetleri Meslek Yüksekokulundaki Durum ve Yürütülen Çalışmalar*
}

\author{
Gökhan AYTEKIN ${ }^{l}$ Senem TURAN ÖZDEMIR ${ }^{2}$ Pelin EDIZ ${ }^{3}$ Fikret CEYLAN ${ }^{4}$ \\ ${ }^{1,2,3,4}$ Uludağ Üniversitesi, Sağllk Hizmetleri Meslek Yüksekokulu, Bursa, Türkiye
}

\begin{abstract}
Giriş
Meslek yüksekokullarının hedefi kaliteli üretimi veya hizmeti gerçekleştirebilecek, bilimsel ve teknolojik gelişmeye uyum sağlayabilecek, iş hayatına yüksek nitelikli ve performanslı ara kademe insan gücü yetiştirmektir (Uluslararası Mesleki ve Teknik Eğitim Konferansı). Bir ürün çıktısı olan teknik üretim modellerinde yaratım ve kontrol kademesi (mühendis) ile üretim kademesi (işçi ve teknisyen) arasındaki geçişi sağlayan ve yönlendiren tekniker ara eleman olarak tanımlanırken, sağlık hizmetlerinin multidisipliner yapısı içerisinde sağlık teknikeri tanımı ara elemandan çok teknik işlemleri yapan, yükssek teknik bilgi ve beceriye sahip yetişmiş Yardımcı Sağlık Personeli olarak tanımlanmalıdır. Oldukça önemli bir insan kaynağı yetiştiren Sağlık Hizmetleri Meslek Yüksekokulları; Sağlık Teknikeri yetiştirerek ülke çapında, sağlık alanında büyük bir iş yükünü karşılamaktadırlar.

Sağlık insan gücünün (SAİG) niteliği, sağlık hizmetlerinin yeterli, etkili, verimli sunulmasında, teknolojinin doğru kullanımında ve hizmetten yararlananların memnuniyetinde önemli etkenlerden biridir. SAİG niteliğinin en önemli belirleyicisi ise verilen eğitimin yeterliliğidir. Dolayısıyla, eğitimin niteliği SAİG'nün niteliğinde, SAİG'nün niteliği de sağlık hizmetlerinin nitelik ve niceliğinin iyileştirilmesinde, ihtiyaçlara uygun sağlık hizmeti sunumunda başlıca rol oynayan faktörlerdir.
\end{abstract}

\section{Mevcut Durum ve Sorunlar}

Sağlıkta yardımcı sağlık personeli gücünün niteliğini iyileştirmek ve sayısını arttırmak üzere 1983 yllından itibaren üniversiteler bünyesinde ön lisans düzeyinde meslek yüksekokullarında çeşitli programlar (Ambulans ve Acil Bakım Teknikerliği, Tıbbi Dokümantasyon ve Sekreterlik, Tibbi Laboratuvar, Anestezi, Radyoloji, Radyoterapi, Hemodiyaliz, vb.) başlatılmıştır. 2006-2007 Sağlık Hizmetleri Meslek Yüksekokulları bünyesinde toplam 189 programa yaklaşık 5000 kontenjan ayrılmıştır. Toplam 27 farklı program arasında Tibbi Dokümantasyon ve Sekreterlik (\%21,7), Tibbi Laboratuvar $(\% 20,6)$, Radyoloji $(\% 13,8)$, Anestezi (\%9), Ambulans ve Acil Bakım Teknikerliği $(\% 6,4)$ çoğunluğu oluşturmakla birlikte, Adli Tıp Teknikerliği, Hastane Yönetimi ve Organizasyonu, Acil Bakım, Radyoterapi, Hidroterapi, Yaşlı Bakımı gibi programlar da yer almaktadır.

Sağlık hizmetleri meslek yüksekokullarındaki eğitime niteliği açısından bakıldığında; öğretim elemanı, Laboratuvar ve uygulama alanlarının yetersizliği gibi sorunların, üniversitelerin alt yapısına bağlı olarak, farklı derecelerde yaşandığı görülmektedir. 


\begin{abstract}
Bunların yanı sıra sağlık teknikerliğinin aşağıdaki genel sorunlarla karşı karşıya olduğu görülmektedir;

Sağlık Hizmetleri Meslek Yüksekokulu mezunlarının meslek tanımları yoktur,

Yetki ve sorumlulukları belirlenmemiştir,

Kadroları yetersizdir,
\end{abstract}

Eğitim aşamalarında çeşitli sorunları vardır;

Ülkemizde orta öğrenim düzeyinde sağlık meslek lisesi eğitimiyle sağlik insan gücü yetiştirilmeye çalışılmakta ve henüz kendi gelişim süreçlerini tamamlamamış olan adölesan çağındaki gençlere meslek sorumluluğu yüklenilmektedir. Oysa Batı Avrupa ve Amerika Birleşik Devletleri gibi gelişmiş ülkelerde meslek eğitimi, 18 yaşını doldurduktan sonraki devreye rastlayan dönemlerde verilecek şekilde düzenlenmiştir.

Sağl1k Hizmetleri Meslek Yüksekokulu programlarının dersleri ve müfredatları istenilen sıklıkta güncellenememektedir. Dersler, ders içerikleri ve müfredatta ulusal bir birlik oluşturulamamıştır.

Öğrencilerin mesleki bilgi ve becerilerini artıracak uygulama alanlarının bulunmasında yetersizlikler vardır. Ayrıca öğretim elemanları teorik dersler ve mesleki uygulamalar ile ilgili gelişmeleri ve teknolojik değişmeleri yeterli düzeyde takip edememektedir.

Ülkemizde Sağlık Hizmetleri Meslek Yüksekokullarındaki eğitim Mesleki Teknik Eğitim tanımı içine alınmış ve bu statü içinde eğitimin süresi iki yıl dört yarıyıl olarak tanımlanmıştır. Oysa bu eğitim yukarıda bahsi geçen Amerika Birleşik Devletleri'nde Lise eğitiminden sonra iki yıl altı dönem, İngiltere'de ise Lise eğitiminden sonra üç yıl altı dönem olacak şekilde düzenlenmiştir.

Avrupa Birliği'nin Mart 2000'de önüne koyduğu Lizbon Stratejisinin hedefi: “Avrupa'y1 2010 yılına kadar dünyanın en dinamik ve rekabet gücü en yüksek bilgiye dayalı ekonomisi haline getirerek, daha fazla istihdam yaratıp, toplumsal uyumu güçlendirmek ve sürdürülebilir ekonomik büyümeyi gerçekleştirmektir."

$\mathrm{Bu}$ hedefe ulaşmak için Avrupa eğitim öğretim sistemlerini; Bilgi toplumunu yaratacak insan kaynaklarının yetiştirilmesine uygun ve birbiri ile uyumlu hale getirilmeye çalışmaktadır.

Bunun için eğitimde Avrupa Birliğinde uluslararası yeterlikler çerçevesi oluşturulmuştur. Eğitimde uluslararası yeterlikler çerçevesinde bilgiye dayalı ekonomileri oluşturup güçlendirmek için; eğitim öğretimin toplumlardaki rolü yanında, doğası da yeniden sorgulanmakta ve eğitici temelli eğitim modeli yerini öğrenim çıktılarının esas alındığı eğitim modeline bırakmaktadır.

\title{
Uluslararası Yeterlilikler Çerçevesi (Şemsiye Çerçeve );
}

Yükseköğretim sistemleri arasında uluslararası ilişkilendirmeyi ve tanınmayı sağlamak, ulusal çerçevelerin geliştirilmesi için yol gösterici ve referans olmak, oluşturulan alt gruplarda (Avrupa Yükseköğretim Alanı gibi) tanımlanan yeterliliklerin bütün dünyaca tanınmasını sağlamak amacı ile kurgulanan bir sistemdir.

Ulusal Yeterlilikler Çerçevesi;

Ülkelerin toplumsal, kültürel ve ekonomik gerçeklerine en yakın tanımları ve yaklaşımları içeren, Yükseköğretim kurumları tarafından kabul gören ve uygulanabilen, ulusal ve uluslararası paydaşlarca tanınan ve ilişkilendirilebilen derecelerin verilebileceği bir sistemdir.

Yükseköğretim Yeterlilikler Çerçevesi;

Yükseköğretim düzeyindeki eğitim, öğretim ve araştırma ile kazanılan yeterliliklerin ve verilen derecelerin, ulusal eğitim ve öğretim yapılarına uygun uluslararası yeterlilik çerçeveleriyle uyumlu hale getirilmesi yanında ulusal ve uluslararası ölçekte karşılıklı tanınabilmeyi sağlamak için 
kurgulanan bir sistem olarak tanımlanabilir.

Yükseköğretim Yeterlilikler Çerçevesinde Ön Lisans düzeyinde Tanımlanan Yeterlilikler:

Genel/mesleki orta öğretimde kazanılan bilgiler üzerine kurulan ve orta öğretim düzeyi üzerindeki ders kitapları ile desteklenen bir alandaki bilgilere sahip olmak ve o alandaki kavramları belirlenen bir düzeyde kavradığını göstermek,

Alanında problem çözümü için gerekli olan verileri tanımlama, toplama ve kullanmayı etkin bir biçimde yapabilmek; pratik uygulamalarda gereken teorik bilgileri, el ve/veya düşünsel becerileri kullanabildiğini göstermek.

Meslekleri ile tasarımları ve uygulamaları çalışma arkadaşlarına, üstlerine ve servis sağladıkları kişi ve gruplara açık bir biçimde anlatabilmek.

Alanlarında bağımsız olarak öğrenmeyi, öğrendiklerini ve öğrendiklerini uygulayabildiklerini göstermek.

Çalışmalarında öngörülmeyen uygulama ile ilgili sorunları çözme yeteneğini kazanmak,

Objektif olarak performans değerlendirmesi ve denetim yapabilmek,

Alanlarındaki uygulamalarda yeterli olacak düzeyde yabancı dil bilgisine sahip olmak,

Temel Bilgisayar kullanımı bilgisi ile birlikte, mesleğinin gerektirdiği yazılım ve donanım kullanabilme yetkinliğine sahip olmak

Meslekleri ile ilgili toplumsal, bilimsel ve ahlaki değerleri gözetme bilincine sahip olmak,

İş güvenliği konusunda yeterli bilgi ve bilince sahip olmak.

Sağlık teknikerliği eğitim programlarında ulusal yeterlikler henüz tanımlanmamış, ders ve müfredatın bu yeterliklere göre güncelleştirilmeleri yapılamamıştır.

Öğrencinin esas alındığı, eğitim çıktılarına dayalı eğitim yeterince benimsenemediğinden öğreticinin ve ders içeriğinin esas alındığı sistemin uygulaması ağırlıklı olarak varlığını devam ettirmektedir.

\section{ULUDAĞ ÜNIVERSITESİ SAĞLIK HIMETLERI MESLEK YÜKSEKOKULUNDA YÜRÜTÜLEN ÇALIŞMALAR}

Sağlık Teknikerliği eğitiminde Avrupa yeterlilikler çerçevesi kapsamında tanımlanmış olan Ön lisans düzeyine uygun mesleki, kişisel ve iletişim becerilerinin öğrencilerimize kazandırılması, Sağlık Teknikerliğinde meslek tanımlarının ve eğitimde kalite standartlarının ortaya konması ve bu bağlamda okulumuz eğitim programları kitapçıklarının oluşturulması, sektör beklentilerinin karşılanması, ayrıca üniversitemizin akreditasyon çalışmaları kapsamında gerçekleştirilen 2005-2006 eğitim öğretim yılında UÜ Sağlık Hizmetleri Meslek Yüksekokulu öğrencilerine de uygulanmaya başlanan öğrenci ders değerlendirme anketleri ve son sınıf öğrenci anketleri ile eğitim ve öğretimde tespit edilen sorunları çözmeye yönelik olarak, yüksekokulumuzda programlar bazında eğitim komisyonlarının oluşturulmasına karar verilmiştir.

Eğitim komisyonları Uludağ Üniversitesi Sağlık Hizmetleri Meslek Yüksekokulunda mevcut bulunan Anestezi Teknikerliği, Tıbbi Dokümantasyon ve Sekreterlik, Tibbi Laboratuvar ve Radyoloji programları için program başkanları, program danışman öğretim görevlileri ve ilgili öğretim elemanlarından oluşturulmuştur. Eğitim komisyonu üyelerinin belirlenmesini takiben eğitim komisyonu için görev tanımı yapılmış, komisyonun hedefleri ortaya konulmuş ve eğitim komisyonu çalışmaları başlatılmıştır.

Kurumlar veya programlar için minimal gereksinimlerin belirlenmesi ve karşılanması, kurumlar 
arası işbirliğinin güçlendirilmesi, uyumun ve kalite güvencesinin sağlanmasına yönelik olarak ve son yıllarda tercih edilen bir eğitim yöntemi olan "öğrenim çıktısına dayalı" yaklaşım temel alınarak komisyon üyeleri tarafından her bir program için öğrenim çıktılarının tanımlanması hedeflenmiştir. Öğrenim çıktılarının tanımlanmasında akademisyenlerin yanı sıra, işverenlerin ve sektör elemanlarının da görüşlerinin alınmasına yönelik olarak anketler düzenlenmesi planlanmıştır.

\section{Sonuç ve Öneriler}

$\mathrm{Bu}$ bildiride Sağlık Teknikerliği eğitiminin günümüzdeki durumu, birtakım sorunları ve yeniden yapılanması ve uluslararası uygulamalar ile ilgili görüşler ve Uludağ Üniversitesi Sağlık Hizmetleri Meslek Yüksekokulunda yürütülen çalışmalar dile getirilmeye çalış1lmıştır.

Sağlık Hizmetleri Meslek Yüksekokulu programlarının teorik ve uygulama dersleri, öncelikle öğrencilerin pratik becerilerini geliştirmeli ve bunun için gerekli olan mesleki bilgiyi kazandırmayı hedeflemelidir.

Meslek Yüksekokulu programlarının müfredatlarının; değişen ihtiyaçlara cevap verebilmesi ve çağdaş gelişmeler ile paralel yürütülebilmesi için (ilgili lisans öğretim programları ile de koordineli olarak) yeniden ele alınması ve güncellenmesi gerekmektedir.

Öğrencilerin mesleki bilgi ve becerilerini artıracak uygulama alanlarının bulunmasında yetersizlikler vardır. Ayrıca uygulama alanı gözeticilerinin de sık aralar ile hizmet içi eğitimlere tabi tutulmas1 gerekmektedir.

Sınavsız Geçiş Sisteminin uygulanmasının yerine Öğrenci Seçme ve Yerleştirme Sistemi (ÖSYS) ya da yine Yükseköğretim Kurumu tarafından uygulanacak bir başka sınav ile öğrencilerin seçilerek, sağlık ile ilgili bu programlara yerleştirilmeleri öğrenim ve meslek kalitesini artırmada oldukça önemli olacaktır.

Yukarıda bahsi geçen bu durumlar Mesleki Teknik Eğitimde Yeniden Yapılanma gerekliliğini ortaya koyan nedenlerden en önemlileri arasındadır.

SHMYO mezunlarının niteliğinin iyileştirilmesi ve kişisel gelişimlerine katkıda bulunulması açısından; nitelikli bir temel eğitim sonrasında (genel lise eğitimi) yüksekokullara gelmeleri, yüksekokul eğitim programlarının meslek tanımlarına ve sektörel beklentilere uygun, aynı zamanda mezunların alanda yaşadıkları sorunlara dayalı olarak geliştirilmesi, eğitim programına uygun öğretim elemanı kadrosunun sağlanması, teorik ve uygulamalı öğrenme ortamlarının ve laboratuvar alt yapılarının geliştirilmesi ve eğiticilerin yeterli sıklıkla hizmet içi eğitimlere katılımlarının sağlanması gerekmektedir.

Ülkemizde yardımcı sağlık personeli eğitimi orta öğretim düzeyinde verilmeye başlanmaktadır. Orta öğretim seviyesinde eğitim veren bu okullarda eğitim veren personelin nicel ve nitel olarak Önlisans düzeyinde eğitim veren personele göre yeterli olmayışı (üniversiteler bünyesinde yer alan Sağlık Hizmetleri Meslek Yüksekokullarında eğitim okullardaki öğretim elemanlarının yanında akademisyenler ve uzman öğretim üyeleri tarafından da yürütülmekte ve desteklenmektedir.), bu okulların teknik ve alt yapı eksiklikleri gibi göstergeler verilen eğitimin sağlık sektörü için istenilen yeterlikte olmadığını göstermektedir. Ayrıca henüz kendi gelişim süreçlerini tamamlamamış olan adölesan çağındaki gençlere sağlık alanında meslek sorumluluğu yüklenilmeye çalışılması, bu düzeyde yetiştirilmeye çalışılan sağlık personeli niteliğinin ne derecede istenilen düzeyde olabileceği hakkında fikir vermektedir. Batılı ülkelerde yardımcı sağlık personeli eğitiminin lise dönemi sonrası verilmesi, sağlık hizmeti alan ve veren insana verilen değeri göstermekte ve sağlik hizmet kalitesini artırmaktadır. Bu uygulama ülkemiz için de yol gösterici olabilir.

Avrupa birliğine üyelik sürecindeki ülkemizde Sağlık Hizmetleri Meslek Yüksekokullarında, birlik üye ülkeleri tarafından kabul gören uluslararası yeterlikler çerçevesi ve yükseköğretimde yeterlikler çerçevesi ile ilgili çalışmalar henüz başlatılamamıştır. 


\section{Öneriler:}

Orta öğretim düzeyinde yardımcı sağlık personeli eğitimine, yukarıda belirtilmeye çalışılan nedenlerden dolayı, kademeli olarak son verilmeli, eğitim batılı ülkelerdeki modeller de göz önüne alınarak lise sonrası dönemde Ön lisans düzeyinde verilmeli, yardımcı sağlık personeli meslek tanımlarında teknisyen tekniker unvanları tek bir çatıda toplanmalıdır.

Sağl1k Hizmetleri Meslek Yüksekokullarında ulusal düzeyde eğitim komisyonları oluşturularak; ulusal ihtiyaçlar, sektörel beklentiler, mezunların ve eğitimcilerin görüşleri alınması ile yükseköğretimde yeterlikler çevresi kapsamında programlar, müfredatlar ve dersler gözden geçirilmeli, gerekli düzenlemeler ve güncelleştirmeler yapılmalı, müfredatlar, dersler ve ders içeriklerinde ulusal birlik sağlanmalıdır.

Eğitim sistemi gözden geçirilmeli ve öğrenim çıktılarının esas alındığı eğitim modelleri benimsenmelidir.

Öğrenci ve eğiticiler dışında sektör elemanları ve diğer paydaşların da eğitime aktif olarak katılımları sağlanmalıdır.

Sağlık sektörünün doğası gereği sağlık eğitiminin daha kapsamlı olduğu göz önünde tutularak Sağlık Hizmetleri Meslek Yüksekokulları diğer Meslek Yüksekokullarından farklı ele alınmalı, ayrı bir yönetmelik düzenlenerek eğitim süresi uzatılmalı, ders sayıları ve saatleri, kredi toplamları, staj gibi özellikleri yeniden düzenlenmelidir.

Eğitim programları Avrupa Birliği ülkeleri ile uyumlu hale getirilerek Sağlık Hizmetleri Meslek Yüksekokullarının öğrenci ve mezun değişim programlarına katılımı sağlanmalı ve artırılmalıdır. 
